\title{
A new species of Bela Leach in J.E. Gray, 1847a (Conoidea Mangeliidae) from Creta (Mediterranean Sea)
}

\author{
Cesare Bogi', Riccardo Giannuzzi Savelli², Francesco Pusateri ${ }^{3}$ \& Gianni Spada ${ }^{4}$ \\ ${ }^{1}$ via Gino Romiti 37, 57124 Livorno, Italy; e-mail: bogicesare@tiscali.it \\ ${ }^{2}$ Via Mater Dolorosa 54, 90146 Palermo, Italy; e-mail: malakos@tin.it \\ ${ }^{3}$ Via Castellana 64, 90135 Palermo, Italy; e-mail: francesco@pusateri.it \\ 451, Rue de l’Orme Gres, 91640 Vaugrigneuse, France
}

\begin{abstract}
Bela minoica n. sp. (Conoidea Mangeliidae), with paucispiral protoconch, is here described from Creta (Mediterranean Sea).
\end{abstract}

KEY WORDS Gastropoda; Bela; Mangeliidae; new species; taxonomy; Mediterranean Sea.

Received 12.07.2021; accepted 02.09.2021; published online 04.10.2021

\section{INTRODUCTION}

The Mangeliidae P. Fischer, 1883 are currently considered as a well-supported clade of the Gastropoda Conoidea (Bouchet, et al., 2011), worthy of family ranking. It includes about 60 different genera among which Bela Leach in J.E. Gray, $1847 \mathrm{a}$.

Because of taxonomic uncertainty due to lacking of a description (only an indication of Murex nebula as type species in Gray, 1847b), many authors used the generic name Bela for unrelated species currently placed in Propebela (G.O. Sars, 1878), Oenopota (Dall, 1885), Mangelia (Risso, 1826), Lorabela (Thiele, 1912), Haedropleura (B.D.D., 1883) or Curtitoma (Verrill, 1880) and then used Raphitoma (Bellardi, 1847) for species currently placed in Bela (Brusina, 1865; Locard, 1891).

The genus is based on the redescription by Powell (1966: 97) and needs a comprehensive and modern revision. Scarponi et al. (2014) selected a lectotype of Bela nebula (Montagu, 1803) among materials deposited in the Montagu collection at RAMM, Exeter. This lectotype designation restricts the usage of the genus Bela separating it from the genera indicate above.

\section{MATERIAL AND METHODS}

During some excursions to Crete and Cyprus, a certain amount of bioclastic sediment was collected in apnea between 5 and 6 meters deep. After sorting the material, we found some specimens of Bela sp. which after a thorough examination appear to belong to a species new for science.

SEM images were taken with a Hitachi TM4000Plus by Nanovision srl. Light photographs were taken (unless otherwise indicated) by Stefano Bartolini (Firenze) using a Canon EOS 400D digital photo camera, with standard $50 \mathrm{~mm}+$ adapted objectives ( 25 and $12.5 \mathrm{~mm}$ ) for 16 and $8 \mathrm{~mm}$ vintage cine camera.

The number of protoconch whorls has been counted according to the method of Verduin (1977).

ABBREVIATIONS. BOG: Collection Cesare Bogi (Livorno, Italy); MNHN: Musée National Histoire Naturelle, Paris (France); PAG: Collection Attilio Pagli (Sovigliana, Italy); PUS: Collection 
Francesco Pusateri (Palermo, Italy); RAMM: Royal Albert Memorial Museum, Exeter (United Kingdom); SMF: Senckenberg Museum, Frankfurt (Germany); sh: shells.

\section{RESULTS}

\section{Systematics}

Citation of unpublished names is not intended for taxonomic purposes.

Superfamilia CONOIDEA J. Fleming, 1822

Familia MANGELIIDAE P. Fischer, 1883

Genus Bela Leach in J.E.Gray, 1847a

Type species: Murex nebula Montagu, 1803, by subsequent designation (Gray, 1847b)

Ichnusa Jeffreys, 1847: 312 (manuscript name by Clark introduced by Jeffreys in synonymy, not available)

Ginnania Monterosato, 1884: 127 - Type species: Pleurotoma fuscata Deshayes by subsequent designation (Crosse, 1885)

Fehria van Aartsen, 1988: 30 - Type species: Ginnania taprurensis Pallary, 1904, by original designation

Ishnula Gray, 1847b:312 (manuscript name by Clark introduced by Gray in synonymy, not available)

Bela minoica Bogi, Giannuzzi-Savelli et Pusateri n. sp. (Figs. 1-9, 10, 16-21)

http://zoobank.org/urn:lsid:zoobank.org:act:63E57 531-724B-4C7C-8D1F-1A644FA119DF

$=$ ? Bela cycladensis sensu Cecalupo et al., 2008

TYPE MATERIAL. Holotype (height $7.8 \mathrm{~mm}$, width $3.1 \mathrm{~mm})(\mathrm{MNHN}-\mathrm{IM}-2000-35917)$ and 8 paratypes: 1 sh (MNHN-IM-2000-35918), 5 sh (BOG); 1 sh (PAG); 1 sh (PUS 2810).

TyPe Locality. Malia, Crete $\left(35^{\circ} 17,45^{\prime \prime} \mathrm{N}-\right.$ $\left.25^{\circ} 27^{\prime} 57^{\prime \prime} \mathrm{E}\right)$ depth 5-6 m.

Material examined. The type material and: Crete, Malia, 2 sh (beached and juveniles) - BOG Cyprus, Aya Napa, 3 sh (beached) BOG.

DESCRIPTION [in square brackets the data of the holotype]. Shell of average size for the genus. Height $5.8-8.3 \mathrm{~mm}$ [7.8], mean $7.01 \mathrm{~mm}$; width
2-3.1 mm [3.1], mean $2.66 \mathrm{~mm}$; slender outline H/D 2.36-2.92 [2.51], mean 2.64. Protoconch paucispiral, of 1.25-1.40 [1.25] convex whorls, height $435 \mu \mathrm{m}$, width $455 \mu \mathrm{m}$, cylindrical, smooth. Teleoconch of 4.5-6 [6], mean 5.24, slightly convex whorls, suture undulated, evident but not deep. Axial sculpture of 10-12 broad, orthocline ribs on the last whorl, weakly flexuose especially on the upper part, slightly narrower than interspaces, tending to be more rounded and to fade out on the base.

Spiral sculpture of fine and closely set homogeneous cordlets, more marked and less closely set on the first whorls, with very small tubercles at the intersections with growth lines. Microgranules covering homogeneously the whole surface (Figs. 20, 21). Last whorl about $60 \%$ of total height. Aperture about $40 \%$ of total height, elongate, with outer lip narrow, smooth internally, anal sinus weak, siphonal canal short, open.

Columella simple, straight, slightly sinuose anteriorly, columellar lip not expanded. Coloration uniformly milky white or creamy white, occasionally with light yellowish hues on lower part of axial interspaces; protoconch and part of first teleoconch whorl brownish.

Soft part unknown.

ETyMology. From the Latin word minoicus, adj. derived from Minos, the mythical king of Crete and with reference to minoic civilization.

Distribution. This species is so far known only from examined material.

REMARKS. The species depicted by Cecalupo et al. (2008 pl. 67 fig. 25) as Bela cycladensis and coming from Sidi Garous (NE Djerba Isl.) could be a $B$. minoica but the small figure does not allow precise identification even if its protoconch seems to be paucispiral.

All the Mediterranean Bela species described so far have multispiral protoconch except Bela plicatilis (Risso, 1826), B. taprurensis (Pallary, 1904), Bela zenetouae (Van Aartsen, 1988) and B. minoica n.sp. Among the species with paucispiral protoconch Bela minoica is the most similar to Bela plicatilis, they have a similar outline but $B$. minoica is distinguished by its larger size (reaching $8.3 \mathrm{~mm}$ ), slightly smaller protoconch (1.25-1.4 vs. 1.5 whorls), less convex whorls, less robust axial ribs, and more evident spiral sculpture. The teleoconch color is uniformly white (except the first whorl), while the lectotype of 


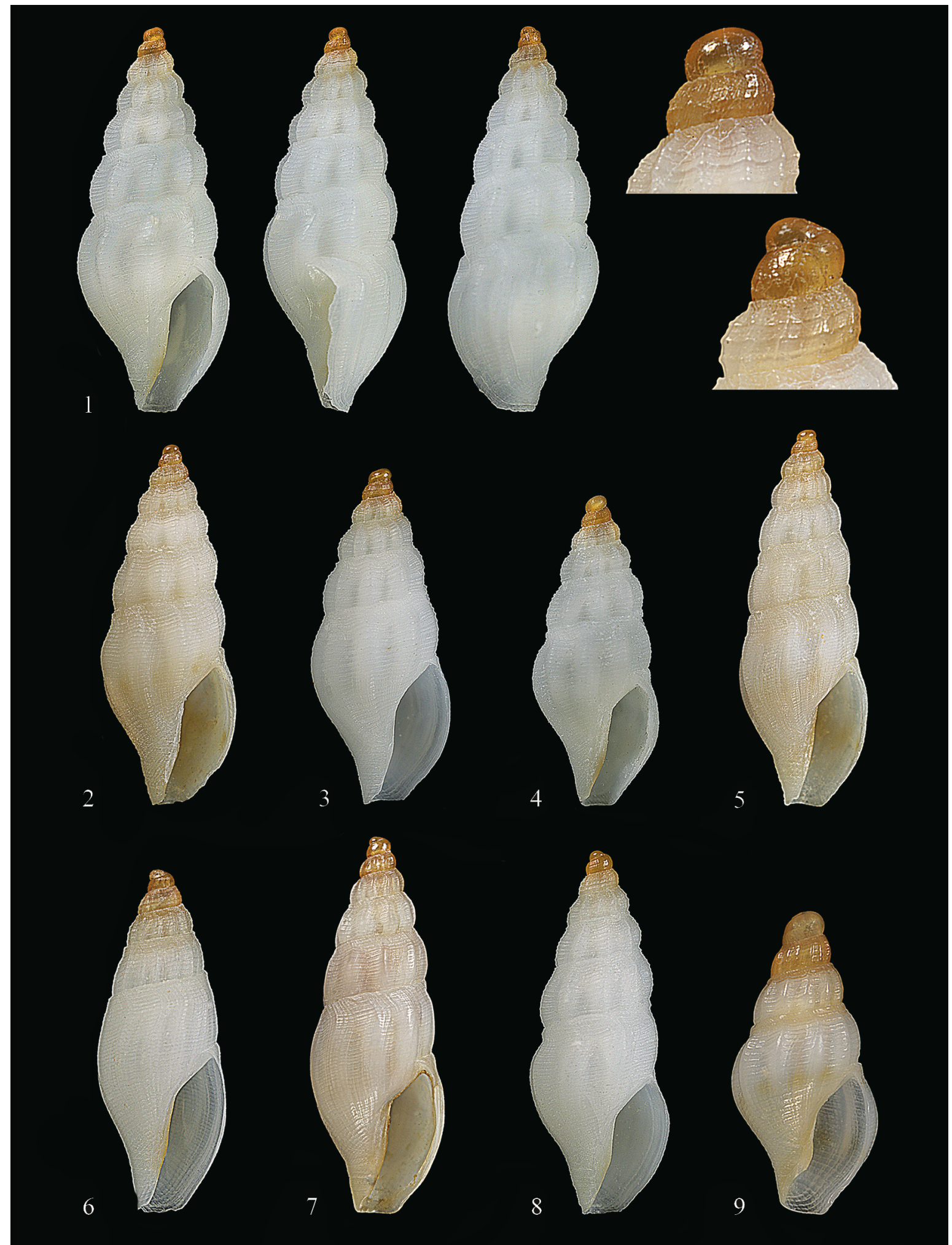

Figures 1-9. Bela minoica n. sp. Malia (Crete) -5-6 m. Fig. 1: Holotype (MNHN-IM-2000-35917), h: 7.8 mm. Fig. 2: paratype 1, h: 7.5 mm (PUS). Fig. 3: paratype 2, h: 6.5 mm (MNHN-IM-2000-35918). Fig. 4: paratype 3, h: 5.8 mm (PAG). Fig. 5: paratype 4, h: $8.3 \mathrm{~mm}$ (BOG). Fig. 6: paratype 5, h: $6 \mathrm{~mm}$ (BOG). Fig. 7: paratype 6, h: $7.3 \mathrm{~mm}$ (BOG). Fig. 8: paratype 7, h: $6.9 \mathrm{~mm}$ (BOG). Fig. 9: young specimen, h: $2.9 \mathrm{~mm}$ (BOG). 


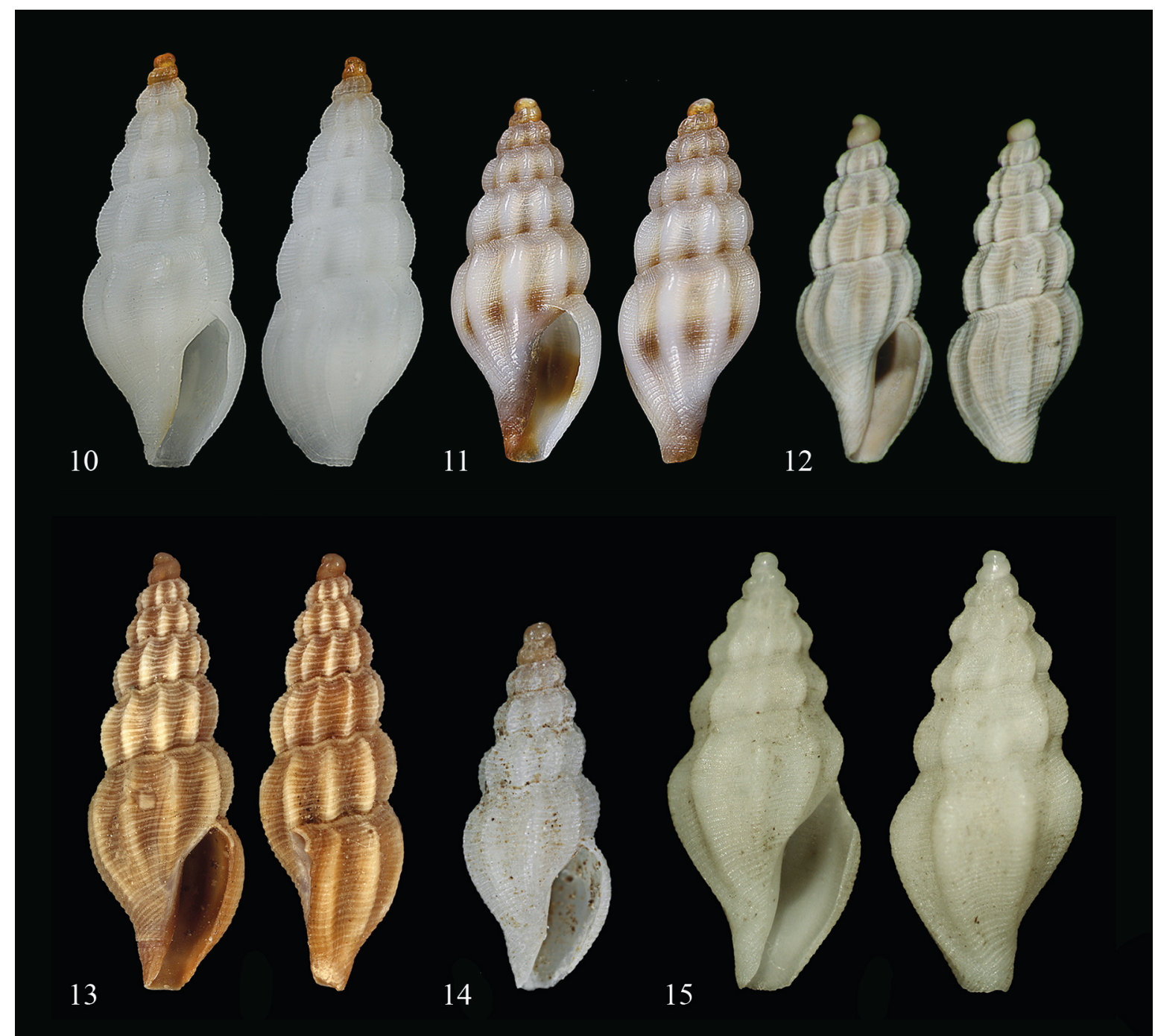

Figure 10. Bela minoica n. sp. Malia (Crete) -5-6 m. Holotype. Figure 11. Bela cfr. plicatilis (Risso, 1826), Cyprus, h: 5.5 mm. Figure 12. Bela taprurensis (Pallary, 1904), Sfax, h: $5.2 \mathrm{~mm}$. Figure 13. Bela cycladensis conspicua (Nordsieck, 1977), Sfax, h: 7 mm, Lectotype here designed (SMF 360290). Figure 14. Bela cycladensis conspicua (Nordsieck, 1977), Sfax, h: $5.7 \mathrm{~mm}$, paralectotype (SMF 360290). Figure 15. Bela zenetouae (Van Aartsen, 1988), Sfax, h: 6.9 mm. Photo courtesy: Carlo Smriglio (F) and Sigrid Hof (D, E - SFM)

B. plicatilis (Spada, 2016) has a creamy whitish background with vertical brownish stripes in the interspaces between the ribs, brown base and yellowish-brown aperture. The shell surface is densely covered with microgranules which appear to be absent in plicatilis. The type locality of $B$. plicatilis is Côte d'Azur (France), but some specimens similar to the lectotype were found also at Sardinia and Cagliari (Italy). Our specimen of Bela cfr. plicatilis from Cyprus (Fig. 11) is quite similar to the lectotype, but we think it could be a different species as it has a significantly smaller protoconch.
Bela taprurensis (Fig. 12) is distinguished from B. minoica by its more slender profile, more convex whorls, more marked sutures and axial ribs, thicker and more spaced spiral cordlets, lack of microgranules on the surface of teleoconch, and by having often uniformly brownish or yellowish shell.

Bela zenetouae (Fig. 15) is easily distinguished from $B$. minoica by its biconical outline and color, being often uniformly brownish with a whitish band on the middle of the last whorl.

Nordsieck (1977: 44; pl. 11 fig. 89) described $B$. cycladensis conspicua from Sfax (Figs. 12, 13). In 


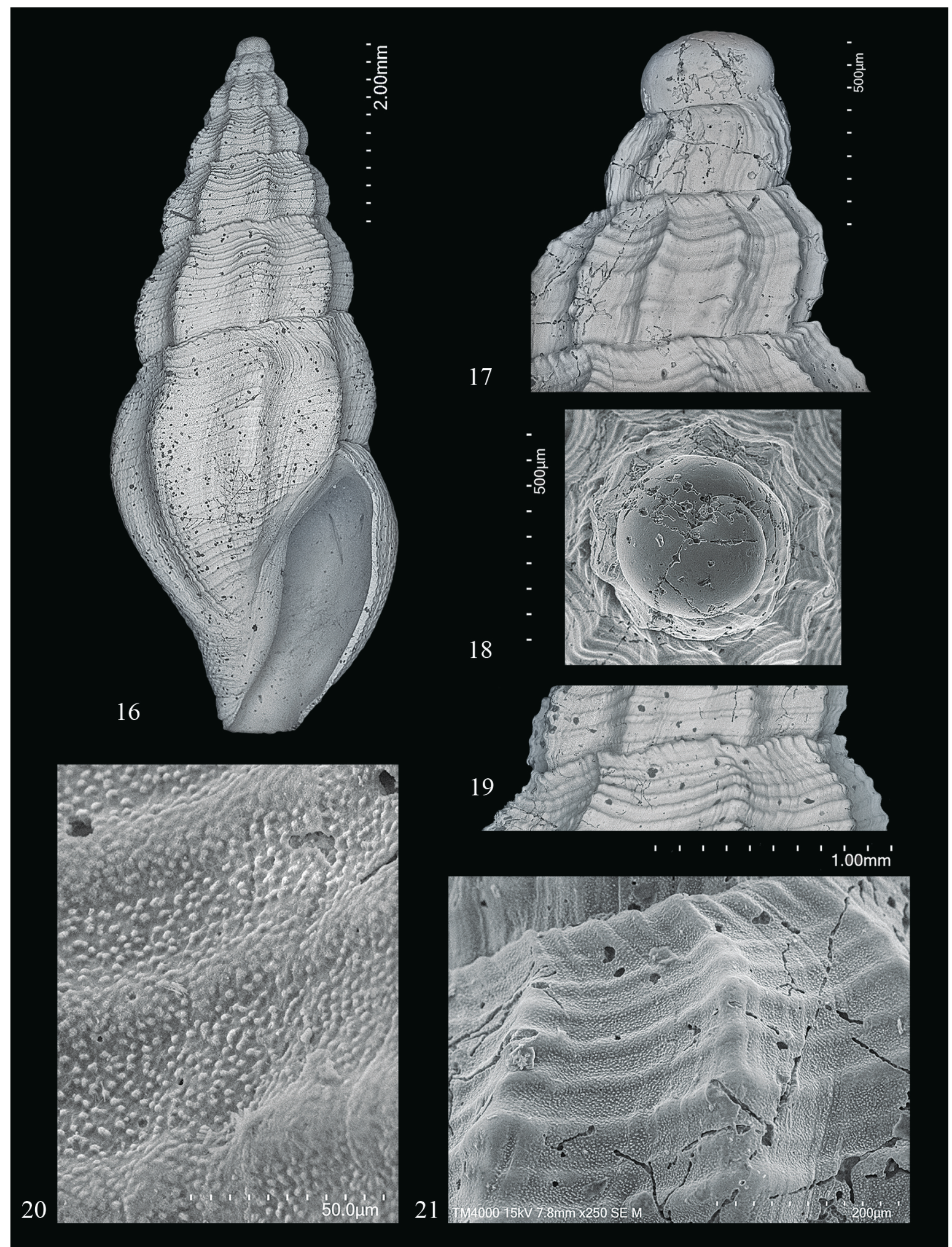

Figures 16-21. Bela minoica n. sp. Malia (Crete) -5-6 m. Holotype (MNHN-IM-2000-35917), h: 7.8 mm. Fig. 16: frontal view of shell. Fig. 17: dorsal view of protoconch. Fig. 18: apical view of protoconch. Fig. 19: particular of sutural zone. Fig. 20: microgranules on the shell surface. Fig. 21: particular of the scuplture. 
the SMF there are 21 specimens (SMF 360290) from Sfax labeled by Nordsieck himself. Among these, R. Jansen has separated a specimen (perhaps that of Nordsieck's figure 89) which we designate here as a lectotype. All the specimens of the lot refer to $B$. $t a-$ prurensis, a rather common species in the gulf of Gabés. Nothing to do with B. cycladensis (Reeve, 1845 ) which has a multispiral protoconch. Thus $B$. cycladensis conspicua Nordsieck, 1977 is an objective junior synonym of B. taprurensis (Pallary, 1904).

\section{AKNOWLEDGEMENTS}

We thank all the friends mentioned above with their acronyms, who have made the material of their collections available to us for study; Sigrid Hof (SMF) fro the photos of material from Nordsdieck collection; Stefano Bartolini (Firenze, Italy), Attilio Pagli (Sovigliana, Italy), Luigi Romani (Lammeri, Italy), Paolo Mariottini (Roma, Italy), Carlo Smriglio (Roma, Italy), Jakov Prkić (Split, Croatia) for the useful discussions. This work was financially supported by Associazione Naturama, Palermo (Italy).

\section{REFERENCES}

Bouchet P., Kantor Y.I., Sysoev A. \& Puillandre N., 2011. A new operational classification of the Conoidea. Journal of Molluscan Studies, 77: 273-308.

Brusina S., 1865. Conchiglie Dalmate inedite. Verhandlungen der Kaiserlich-Königlichen Zoologisch-Botanischen Gesellschaft in Wien, 15: 3-42.

Bucquoy E., Dautzenberg P. \& Dollfus G., 1882-1886. Les Mollusques Marins de Roussillon. Tome Premier: Gastropodes avec Atlas de 66 Planches. J.-B. Baillière \& Fils, Paris, 570 pp., 66 pls. [Cited portion was published in 1883 includes pp. 85-196, pls. 11-20.]

Cecalupo A., Buzzurro G. \& Mariani M., 2008. Contributo alla conoscenza della malacofauna del Golfo di Gabès (Tunisia). Quaderni della Civica Stazione Idrobiologica di Milano, 31: 1-175, 91 pls.

Dall W.H., 1885. New or specially interesting shells of the Point Barrow expedition. Proceedings of the United States National Museum, 7: 523-526, pl. 2.

Gray J.E., 1847a [Oct.]. On the classification of the British Mollusca by W.E. Leach. Annals and Magazine of Natural History, (1) 20: 267-273.

Gray J.E., $1847 \mathrm{~b}$ [Nov.] A list of the genera of Recent Mollusca, their synonyma and types. Proceedings Zoological Society London, 15: 129-219.
Jeffreys J.G., 1847. Descriptions and notices of British shells. Annals and Magazine of Natural History, series 1, 14: 309-314.

Locard A., 1891. Les coquilles marines des côtes de France. Annales de la Société Linnéenne de Lyon, 37 : $1-385$.

Monterosato T. di M., 1884. Nomenclatura generica e specifica di alcune conchiglie mediterranee. Stabilimento Tipografico Virzi, Palermo, 152 pp.

Nordsieck F., 1977. The Turridae of the European Seas. Roma, Ed. La Piramide, pp. 131, 26 pls.

Pallary P., 1904. Addition a la faune malacologique du Golfe de Gabès. Journal de Conchyliologie, 52: 212248, pl. 7.

Powell A.W.B., 1966. The molluscan families Speightiidae and Turridae an evaluation of the valid taxa, both Recent and fossil, with lists of characteristic species. Bulletin of the Aukland Institute and Museum, 5: 1-184.

Risso A., 1826. Histoire Naturelle des Principales Productions de l'Europe Méridionale et Particulièrement de Celle des Environs de Nice et des Alps Maritimes. Vol. 4. F.-G. Levrault, Paris, vii + 439 pp., 12 pls.

Sars G.O., 1878. Bidrag til Kundskaben om Norges arktiske Fauna. I. Mollusca Regionis Arcticae Norvegiae. Oversigt over de i Norges arktiske Region Forekommende Bløddyr. Brøgger, Christiania. xiii + 466 pp., pls. 1-34 \& I-XVIII.

Scarponi D., Landau B., Janssen R., Morgenroth H. \& Della Bella G., 2014. Lectotype designtion for Murex nebula Montagu 1803 (Mangeliidae) and its implications for Bela Leach in Gray 1847. Zootaxa 3888(1): $45-54$.

Spada G., 2016. Bela plicatilis (Risso, 1826) a valid species (Gastropoda, Conoidea, Mangeliidae). Bollettino Malacologico, 52: 77-78.

Thiele J., 1912. Die antarktischen schnecken und muscheln. Deutsche Südpolar-Expedition (1901-1903) 13: $183-286$

van Aartsen J.J., 1988. European Mollusca: notes on less well known species. XII. Bela menkhorsti nom. nov. = Pleurotoma nana Scacchi, 1836 non Deshayes, 1835 and Fehria (nov. gen.) zenetouae nov. spec. La Conchiglia, 20(232/233), 30-31.

Verduin A., 1982. How complete are diagnoses of coiled shells of regular build? A mathematical approach. Basteria, 45: 127-142.

Verrill A.E., 1880. Notice of recent addition to the marine Invertebrata of the northeastern coast of America, with descriptions of new genera and species and critical remarks on others. Part II - Mollusca, with notes on Annelida, Echinodermata, etc, collected by the United States Fish Commission. Proceedings of the United States National Museum, 3: 356-409. 